\title{
Influence of the Inclination of Sugarcane Stalks on Their Sucrose Content
}

\author{
Severiano Alers Alers and George Samuels ${ }^{1}$
}

\section{INTRODUCTION}

It is generally recognized that lodging in sugarcane exerts a harmful effect on sugar yield, but exact figures as to the losses involved are scarce. Borden' has reported the results of a pot experiment. When the plants were 8 months old, half of the pots were placed on their sides with the stalks horizontal. At harvest 5 months later lodging had resulted in an average loss of 25 percent of the sugar and, curious to relate, the loss was largely restricted to the lower portion of the stalk which had already matured when lodging occurred. The average loss of 25 percent was caused by poorer juice qualities.

Narasimha $\mathrm{RaO}^{3}$, in a pot experiment, bent individual 8-month Co. 419 canes at angles of $30^{\circ}, 45^{\circ},\left(60^{\circ}\right.$, and $75^{\circ}$ from the vertical and harvested 45 days after inclination. The inclined (lodged) canes showed inferior juice qualities as compared with the erect canes. The lowering in the sucrose of the juice significantly increased with the degree of inclination of the stalk from the vertical. Accumulation of reducing sugars was found to be higher in the juices of inclined canes, but no definite trend was discernible related to the extent of inclination.

In Puerto Rico high winds accompanied by heavy rains many times cause severe lodging of sugarcane. Lodging caused damage to the sugarcane crop from the very high winds and heavy rains of the hurricane Donna which touched Puerto Rico in 1956. Lodging of the sugarcane might be due to the senescence of the roots as the crop ages, shallow rooting, and excess nitrogen fertilization which causes increased succulence, a lower fiber content, and the development of heavy tops.

It is a well-known fact that lodged plants tend to develop suckers. These suckers, if allowed enough time to grow, will contribute to a lowering of the sucrose content of the cane harvested, inasmuch as the harvested suckers are lower in sucrose than the mature inclined cane.

An experiment was undertaken by the Agronomy and Horticulture De-

'Assistant Agronomist and Agronomist, respectively, Agricultural Experiment Station, University of Puerto Rico, Río Piedras, P.R.

${ }^{2}$ Borden, R. J., Juice quality affected by lodging, Hawaiian Planters' Rec. 4639 $42,1942$.

${ }^{3}$ Narasimka Rao, G., Influence of the inclination of cane stalks on their juice quality, Sugarcane Research Sta., Anakapalle, Andhra Pradesh, India. (mimeographed paper). 
partment of this Agricultural Experiment Station to study the influence of the inclination, or lodging, of sugarcane on the sucrose content of the cane under field conditions. This paper reports the results of this investigation.

\section{PROCEDURES}

The experiment was established at the Solís Farm at Río Piedras in a field of P.R. 980 which was 7 months old. A cane row approximately 250 long was used for the treatments. Two rows of cane were cut down on either side of the chosen row and removed to permit the various inclination treatments to be carried out.

The treatments consisted of inclining canes at $30^{\circ}, 45^{\circ}$, and $60^{\circ}$ from the vertical. This was accomplished by tying the inclined canes to a wire stretched between two posts. The posts and the wire were located at a predetermined distance from the stalk, so that the chosen stalks were inclined at the proper angle.

A stool of cane was chosen for each treatment. A minimum of 12 stalks of equal height were chosen. Six of the stalks were inclined to the proper angle and at least six stalks were allowed to remain erect or vertical. Thus every inclination treatment had an erect or $0^{\circ}$ inclination check. The treatments were replicated nine times in a randomized block design.

The experiment was harvested at 30,60 , and 120 days after inclination. A minimum of two stalks were harvested at each cutting. The experiment was initiated on September 21, 1961.

\section{RESULTS}

The results of the various degrees of inclination on the components of sucrose are given in table 1.

For all components of sucrose measured, sucrose-percent-cane, sucrosepercent-juice, purity, polarization, and Brix, there were no appreciable differences that could be attributed to the degree of inclination of the sugarcane. There was no confirmation of the work of either Borden or Roa since, in their work, lodging or increasing the degree of inclination of the sugarcane decreased its sucrose content. In fact, in our study, as shown in table 1, there was a tendency for the sucrose-percent-cane and sucrose-percent-juice to increase at the $30^{\circ}$ and $45^{\circ}$ inclinations, whereas at $60^{\circ}$ the values averaged about those of the erect canes. The purity of the cane reflected very little change attributable to the degree of inclination.

Considering the days the canes were inclined before harvesting, we find that, at 30 days, there was more variation in sucrose-percent-cane than at 60 or 120 days (table 1). For sucrose-percent-juice, purity, polarization, and Brix, 60 days of inclination caused the most variation in the factors cited. 
TABLE 1.-The effect of the degree of inclination of sugarcane on its sugar components

\begin{tabular}{c|c|c|c|c|}
\hline \multicolumn{3}{|c}{ Results for indicated inclination irom the vertical } \\
Days from inclination \\
to harvest
\end{tabular}

Sucrose-percent-cane

\begin{tabular}{c|r|r|r|r}
\hline 30 & 8.69 & 9.78 & 9.99 & 8.63 \\
60 & 9.47 & 9.73 & 10.27 & 9.49 \\
120 & 11.13 & 11.28 & 11.02 & 11.16 \\
\cline { 2 - 4 } Average & 9.76 & 10.26 & 10.43 & 9.76 \\
\hline
\end{tabular}

Sucrose-percent-juice

\begin{tabular}{|c|c|c|c|c|}
\hline $\begin{array}{r}30 \\
60 \\
120\end{array}$ & $\begin{array}{l}12.67 \\
14.65 \\
16.92\end{array}$ & $\begin{array}{l}13.22 \\
15.78 \\
17.41\end{array}$ & $\begin{array}{l}13.71 \\
16.10 \\
17.52\end{array}$ & $\begin{array}{l}11.00 \\
15.81 \\
17.72\end{array}$ \\
\hline Average & 14.75 & 15.47 & 15.78 & 14.84 \\
\hline \multicolumn{5}{|c|}{ Purity } \\
\hline $\begin{array}{r}30 \\
60 \\
120\end{array}$ & $\begin{array}{l}84 \\
87 \\
92\end{array}$ & $\begin{array}{l}85 \\
89 \\
91\end{array}$ & $\begin{array}{l}85 \\
90 \\
91\end{array}$ & $\begin{array}{l}84 \\
90 \\
91\end{array}$ \\
\hline Average & 88 & 88 & 89 & 88 \\
\hline \multicolumn{5}{|c|}{ Polarization } \\
\hline $\begin{array}{r}30 \\
60 \\
120\end{array}$ & $\begin{array}{l}53.8 \\
61.5 \\
72.5\end{array}$ & $\begin{array}{l}56.0 \\
65.8 \\
72.0\end{array}$ & $\begin{array}{l}57.7 \\
66.7 \\
72.5\end{array}$ & $\begin{array}{l}51.2 \\
65.4 \\
73.3\end{array}$ \\
\hline Average & 62.6 & 64.6 & 65.6 & 63.3 \\
\hline \multicolumn{5}{|c|}{ Brix } \\
\hline $\begin{array}{r}30 \\
60 \\
120\end{array}$ & $\begin{array}{l}15.8 \\
17.2 \\
19.2\end{array}$ & $\begin{array}{l}16.3 \\
18.0 \\
19.1\end{array}$ & $\begin{array}{l}16.4 \\
18.0 \\
19.2\end{array}$ & $\begin{array}{l}15.1 \\
17.8 \\
19.4\end{array}$ \\
\hline Average & 17.4 & 17.8 & 17.9 & 17.4 \\
\hline
\end{tabular}


nI their experiments Borden and Roa utilized pots in the greenhouse, whereas in this study use was made of sugarcane growing in the field. Borden had placed his pots horizontal for 5 months, giving a $90^{\circ}$ inclination, whereas the extreme degree of inclination in this study was $60^{\circ}$. It was impossible to bend the canes beyond $60^{\circ}$ from vertical in the field study without breaking the cane stalk. These factors may be responsible for the fact that, in this study, the degree of inclination or lodging of the cane caused no appreciable variation in the sucrose content of the sugarcane.

It would seem that such severe inclination of the sugarcane as to render it almost horizontal would damage the cane. Such severe cases of lodging caused by high winds to shallow-rooted canes actually expose the root systems to the air and cause breaking of many of the canes at the base of the stool. However, the study undertaken here indicates that a degree of inclination of up to $60^{\circ}$ from vertical did not depress sucrose formation in the sugarcane P.R. 980.

\section{SUMMARY}

A field test was conducted with a ratoon of P.R. 980 to determine the influence that the degree of inclination of sugarcane from the vertical, or lodging, has on the sucrose components. The sugarcane was inclined at angles of $30^{\circ}, 60^{\circ}$, and $90^{\circ}$ from the vertical for 30,60 , and 120 days. There was no appreciable difference in sucrose components that could be attributed to the degree of inclination from the vertical. There were small increases in sucrose-percent-cane, sucrose-percent-juice, and polarization for the $30^{\circ}$ and $60^{\circ}$ treatments at 30 and 60 days. However, the purity and Brix tended to show very little variation that could be attributed to the degree of inclination.

\section{RESUMEN}

Se llevó a cabo una prueba de campo con un retoño de caña de azúcar de la variedad P.R. 980 para determinar el efecto del grado de inclinación de la caña sobre su contenido de sacarosa. La caña se inclinó adrede de la posición vertical a ángulos de $30^{\circ}, 60^{\circ}$ y $90^{\circ}$ por espacio de 30,60 y 120 días. No hubo diferencia apreciable en el contenido de sacarosa en la caña que pudiera atribuirse al grado de inclinación que se puso. Hubo pequeños aumentos en la sacarosa en caña, sacarosa en jugo y polarización de la caña inclinada a $30^{\circ}$ y $60^{\circ}$ por 30 y 60 días. Sin embargo, la variación que reflejaron la pureza y el Brix fue tan pequeña que no pudo atribuírsele al grado de inclinación. 